\title{
PERLINDUNGAN HUKUM TERHADAP KONSUMEN ATAS INFORMASI IKLAN PERUMAHAN YANG MENYESATKAN DALAM PERJANJIAN KEPEMILIKAN RUMAH PADA PT. BANGUN PERSADA SEJAHTERA
}

\author{
Budi Setiawan $^{1}$, Ferdi ${ }^{2}$, Iyah Faniyah ${ }^{3}$ \\ Program Studi Pascasarjana Ilmu Hukum \\ Universitas Ekasakti Padang
}

\begin{abstract}
Nowadays the needs of the house are difficult to obtain, although the government is always active and strives to carry out housing development. In the midst of the limited ability of the government, has led to business opportunities to meet the needs of community housing, commonly referred to as developers. Developers in providing homes often do not provide clear information relating to the specification conditions of the house to the consumer. The problems discussed in this thesis writing is, first how the form of legal protection of the consumer for misleading housing ad information? Second, how is the business actor's responsibility for misleading home advertising information? This research is an analytical descriptive research, with normative juridical approach as main approach and empirical juridical as supporter. The data used are secondary data and primary data collected through literature study and field study with interview technique. The analysis is done qualitatively and presented in the form of qualitative descriptive. Based on the results of research that has been analyzed it can be concluded, firstly, forms of legal protection of misleading housing ad information, for the actions undertaken by developers PT. Bangun Persada Sejatera to Villa Anggrek housing consumer, the consumer as an injured party can make various legal efforts to fight for his rights through: the settlement of consumer dispute through litigation and settlement of non-litigation consumer disputes. Secondly, the business actor's responsibility for misleading housing advertising information is that the consumer is entitled to submit his / her complaint relating to the house in the maintenance warranty period of 100 (one hundred) calendar days. Developers as business actors will seek every improvement that complained by consumers. If the consumer feels aggrieved by the business actors, the entrepreneur shall be obliged to provide compensation, compensation and / or reimbursement for loss caused by the user, user and the utilization of the goods and / or services that have been traded.
\end{abstract}

Kata Kunci : Perlindungan Hukum, Konsumen, dan Perjanjian

\section{PENDAHULUAN}

Perlindungan hukum terhadap konsumen atas informasi yang menyesatkan tentang Perumahan sangatlah penting, untuk itu perlu diketahui oleh masyarakat ada 3 hal 1) Perumahan merupakan kebutuhan primer sehingga semua orang pasti menghendaki dan ingin memiliknya. 2) Dorongan sebagai pelaku usaha di bidang perumahan.3) Cara penyampaian informasi melalui iklan.

Dalam era globalisasi saat ini perkembangan komunikasi dan informasi berjalan sangat pesat sejalan dengan laju pembangunan segala bidang. Hal tersebut 
menuntut suatu gerak manusia yang cepat, efisien dan mudah agar segala kebutuhan dapat segera terpenuhi. Globalisasi informasi dalam politik, ekonomi, sosial dan budaya berkembang dengan baik karena cepatnya jaringan informasi.

Melihat perkembangan ekonomi dan pembangunan di bidang industri serta perdagangan nasional telah menghasilkan berbagai macam dan variasi barang dan jasa yang bisa dikonsumsi. Demikian juga globalisasi perdagangan bebas juga di dukung dengan kemajuan teknologi telekomunikasi dan informatika telah memperluas ruang gerak arus transaksi yang ditawarkan bervariasi. $^{1}$

Kebiasaan dari masyarakat konsumtif merupakan pangsa sekaligus tantangan bagi para pelaku usaha untuk memasarkan sebanyak mungkin perumahan, salah satu alat yang selalu digunakan oleh para pelaku usaha untuk memasarkan semua produk-produknya termasuk perumahan adalah dengan cara menggunakan media iklan. Undang-undang Nomor 8 Tahun 1999 tentang Perlindungan Konsumen, promosi adalah merupakan suatu kegiatan pengenalan atau usaha penyebar luasan informasi suatu barang dan/atau jasa yang akan dan sedang di perdagangkan.

1 Zulkarnaen ,Perlindungan Hukum Terhadap Konsumen Barang Barang Elektronik.PT. Gramedia, Semarang 2008.
Hal pokok dan utama dalam perlindungan konsumen adalah masalah kenyamanan, keamanan, dan keselamatan konsumen. Konsumen diberikan hak untuk memilih barang/jasa yang dikehendaki berdasarkan atas keterbukaan informasi yang benar, jelas, dan jujur. Konsumen berhak untuk didengar, memperoleh advokasi, pembinaan, perlakuan yang adil, kompensasi sampai ganti rugi dalam hal terjadi penyimpangan pelaku usaha yang merugikan. Perkembangan perekonomian yang pesat menghasilkan berbagai jenis barang dan/atau jasa yang dikonsumsi. Konsumen juga dihadapkan pada berbagai jenis barang dan/atau jasa yang ditawarkan secara variatif. Kondisi seperti ini memberikan manfaat bagi konsumen karena kebutuhan barang dan/atau jasa dapat terpenuhi, tetapi di sisi lain mengakibatkan kedudukan pelaku usaha dan konsumen menjadi tidak seimbang. Konsumen menjadi objek pelaku usaha untuk meraup keuntungan sebesar-besarnya melalui promosi, cara penjualan, serta penerapan perjanjian standar yang merugikan konsumen. ${ }^{2}$

Peranan penting developer sebagai pelaku usaha di industri perumahan adalah memberikan informasi penting, jelas dan akurat kepada konsumen mengenai produk

\footnotetext{
${ }^{2}$ Yusuf Shofie, Perlindungan Konsumen dan Instrumen - instrumen Hukumnya, PT. Citra Aditya Bakti, Bandung,, 2009, hlm. 91
} 
yang ditawarkan, seperti informasi jenis hak atas tanah, kondisi fisik bangunan, dan harga jual. Pentingnya pemberian informasi kepada konsumen bukanlah tugas pelaku usaha semata, melainkan juga tugas konsumen untuk mencari informasi yang dapat dipergunakan untuk membuat suatu keputusan tentang penggunaan barang dan/atau jasa tersebut.

Salah satu developer di kota Padang, PT.Bangun Persada Sejahtera mendirikan perumahan bersubsidi dan non-subsidi. Perumahan ini merupakan proyek kerjasama antara developer PT. Bangun Persada Sejahtera dengan Bank BTN Padang dalam menyalurkan Kredit Pemilikan Rumah (KPR). Developer PT. Bangun Persada Sejahtera memasarkan perumahan tersebut sejak tahun 2016, saat kondisi rumah masih dalam tahap perencanaan atau belum dibangun. Konsumen banyak yang tertarik untuk membeli rumah di perumahan yang ditawarkan oleh developer tersebut, dikarenakan lokasi yang cukup strategis, harga yang tidak terlalu mahal dan cara pembayaran yang cukup bervariasi.

Pentingnya media iklan bagi pelaku usaha dapat tergambarkan dalam pendapat yang di sampaikan oleh David Oughton dan John Lowry,yang menulis bahwa Advertising is the central symbol of consumer

${ }^{3}$ Dedi Harianto. Perlindungan Hukum Bagi Konsumen Terhadap Iklan Yang Mnyesatkan, Ghalia Indonesia. Bogor.2010, hlm.45 society, advertising plays a central role in making available to consumer information which the producers of the advertised product wishes the consumer to have (periklanan adalah simbol utama dari masyarakat konsumen, iklan memainkan peran penting dalam membuat tersedia informasi untuk konsumen dimana pelaku usaha yang mengiklankan produk berharap konsumen untuk memiliki) ${ }^{3}$. Melalui iklan, pelaku usaha seharusnya dapat lebih mendekatkan diri kepada konsumen, dengan menghasilkan beraneka produk yang sesuai dengan keinginan dan kebutuhan konsumen.

Sampai saat ini Indonesia belum memiliki peraturan khusus setingkat Undangundang guna mengatur kegiatan periklanan akibatnya terjadi pluralism ketentuan periklanan dalam hukum positif yang berlaku,misalnya diatur di dalam Undangundang Nomor 8 Tahun 1999 Tentang Perlindungan Konsumen, Kitab Undangundang Hukum Perdata, Kitab UndangUndang Hukum Pidana, Peraturan Pemerintah dan Peraturan Menteri yang bersifat administratif. Sehingga menyisakan beberapa permasalahan berkenaan penentuan hak dan kewajban pelaku usaha periklanan, adapun bentuk-bentuk penyesatan iklan yang dilarang , Beban pertanggungjawaban pelaku usaha periklanan, kedudukan dewan periklanan 
Indonesia sebagai badan pengawas iklan, sampai pada sanksi yang dapat dijatuhkan kepada pelaku usaha akibat melanggar ketentuan tersebut. ${ }^{4}$

Menurut Janus Sidabalok ada empat alasan pokok mengapa konsumen perlu dilindungi yaitu:

1. Melindungi konsumen sama artinya dengan melindungi seluruh bangsa seperti diamanatkan dan tujuan pembangunan menurut Undang-Undang dasar 1945.

2. Melindungi Konsumen perlu untuk menghindarkan konsumen dari dampak negative pengunaan tehnologi.

3. Melindungi konsumen perlu untuk melahirkan manusia-manusia yang sehat rohani dan jasmani sebagai pelaku-pelaku pembangunan yang berarti juga untuk menjaga kesinambungan pembangunan nasional.

4. Melindungi Konsumen untuk menjaga sumber dana pembangunan yang bersumber dar masyarakat konsumen. ${ }^{5}$

Namun demikian, realitas yang terjadi di masyarakat tidak selamanya berjalan sebagaimana yang di harapkan. Seringkali ditemukan pelaku usaha menyampaikan informasi yang menyesatkan melalui iklan. Penyesatan Informasi barang dan jasa melalui iklan tidak hanya berpotensi merugikan konsumen secara materiil bahkan lebih jauh dapat serta dapat menimbulkan hilangnya

${ }^{4}$ Ibid, hlm.47 kepercayaan konsumen terhadap informasi yang disampaikan oleh pelaku usaha. Oleh sebab itu konsumen mempunyai hak untuk meminta pertanggungjawaban pelaku usaha terhadap penyampaian iklan yang menyesatkan tersebut.

Berdasarkan uraian diatas, saya tertarik untuk mengetahui dan Menganalisis Bagaimana Perlindungan Hukum Terhadap Konsumen Atas Informasi Iklan Perumahan Yang Menyesatkan Dalam Perjanjian Kepemilikan Rumah Pada PT. Bangun Persada Sejahtera.

\section{METODE PENELITIAN}

Untuk menjawab permasalahan seperti yang telah diuraikan diatas, maka dalam melaksanakan penelitian yang berfungsi sebagai acuan, sehingga hasil dari penelitian dapat menemui sasaran dan dapat dipertanggung jawabkan.

Penelitian ini menggunakan pendekatan yuridis normatif sebagai pendekatan utama dan di dukung pendekatan yuridis empiris. Pendekatan yuridis normatif digunakan untuk menganalisis berbagai peraturan perundang-undangan terkait dengan perlindungan konsumen dan Perseroan Terbatas serta developer. Penelitian hukum normatif disebut juga penelitian doktrinal, biasanya hanya dipergunakan sumber-sumber data sekunder saja, yaitu peraturan perundang

\footnotetext{
5 Janus Sidabalok,Hukum Perlindungan Konsumen di Indonesia,Bandung.PT Citra AdityaBakti 2006, hlm 6
} 
- undangan, teori hukum dan pendapat sarjana hukum terkemuka. ${ }^{6}$ Sedangkan pendekatan yuridis empiris digunakan untuk menganalisis hukum yang dilihat sebagai perilaku masyarakat yang berpola dalam kehidupan masyarakat yang selalu berinteraksi dan berhubungan dalam aspek kemasyarakatan. ${ }^{7}$

Setelah data hukum terkumpul primer dan sekunder maupun tersier selanjutnya di lakukan analisa. Langkah-langkah analisis dalam penelitian hukum normative ini adalah sesuai dengan pendapat Peter Mahmud Marzuki yaitu :

1. Mengidentifikasi fakta hukum dan mengeliminasi data yang tidak relevan.

2. Mengumpulkan data - data hukum dan non hukum yang relevan dengan isu hukum.

3. Menelaah isu hukum berdasarkan data yang di kumpulkan.

4. Memberikan preskripsi berdasarkan argumentasi yang telah di bangun. ${ }^{8}$

Hasil analisis data hukum di bahas menggunakan metode deduktif yaitu bersifat umum ke hal yang bersifat khusus.Kemudian di analisis dan dituangkan dalam bentuk preskripsi sehingga dapat mencapai tujuan yang di inginkan yaitu menjawab rumusan masalah yang ada.

\section{HASIL PENELITIAN}

6 Ronny Hanitijo Soemitro, Metodologi Penelitian Hukum dan Jurimetri, Sinar Grafika, Jakarta, 2002, hlm. 8
Hasil penelitian tentang Pengadaan Perumahan oleh PT. Bangun Persada Sejahtera. PT. Bangun Persada Sejahtera merupakan perusahaan yang bergerak di bidang pengembang perumahan (developer) dan berkantor pusat di kota Padang. Perusahaan ini memiliki visi menjadi perusahaan kontraktor di bidang jasa kontruksi yang meliputi bidang pembangunan perumahan dengan ditunjang total quality managementyang memberikan total quality services bagi para konsumen perumahan. Misi PT. Bangun Persada Sejahtera adalah memberikan pelayanan, mutu, dan kepuasan yang terbaik kepada konsumen, membangun dan menciptakan citra terbaik perusahaan serta turut berpartisipasi dalam pembangunan Negara Kesatuan Republik Indonesia. Tujuan perusahaan adalah memberikan pelayanan dalam mewujudkan impian atau keinginan konsumen dalam bidang jasa konstruksi, baik perencanaan, pengawasan, dan pelaksanaannya yang meliputi pengembang kawasan perumahan.

Tujuan dan aktivitas didirikannya perusahaan adalah untuk memperoleh manfaat ekonomi yang layak dan menguntungkan. Dalam hal ini usaha yang dipilih harus benar-benar memiliki peluang untuk dikembangkan dan memberikan keuntungan bagi perusahaan.

\footnotetext{
7 Amirudin dan Zaenal Asikin, Pengantar Metode Penelitian Hukum, Raja Grafindo Persada, Jakarta, 2006, hlm. 133

8 Ibid, hlm. 171
} 
Saat ini, PT. Bangun Persada Sejahtera masih melaksanakan pembangunan perumahan pada kawasan tersebut. Perumahan Villa Anggrek dibangun sebagai kawasan hunian tempat tinggal dengan cluster system. Perumahan ini memang diperuntukkan untuk semua kalangan masyarakat baik masyarakat kelas menengah ke bawah dan kelas menengah ke atas, dengan beberapa tipe dan ukuran rumah yang dibangun.

Dalam pembelian rumah di Perumahan Villa Anggrek, yang harus ditentukan awal oleh konsumen adalah lokasi blok, jenis, dan tipe rumah yang akan dibeli. Konsumen dapat memita perubahan tata letak (lay out) ruangan dalam rumah maupun pengembangan unit rumah yang akan dibelinya. Hal ini akan berkaitan dengan harga jual dari rumah tersebut. Apabila konsumen sudah setuju dengan lokasi blok, jenis, dan tipe rumah rumah yang akan dibelinya, konsumen diberi kewajiban untuk membayar tanda jadi/booking block dengan jumlah minimal Rp. 5.000.000,- (lima juta rupiah) sebagai jaminan agar lokasi blok tidak dijual lagi pada yang lain. ${ }^{9}$

Tabel 1

Bentuk-bentuk Iklan Perumahan yang

Dilakukan Oleh PT. Bangun Persada Sejahtera

\begin{tabular}{|c|c|c|}
\hline Tahun & Bentuk Iklan & Lokasi \\
\hline 2015 & Surat Kabar dan Brosur & \begin{tabular}{|lll} 
Villa Anggrek I (Lubuk \\
Minturun
\end{tabular} \\
\hline 2016 & Surat Kabar dan Brosur & \begin{tabular}{|lll} 
Villa Anggek II & (Lubuk \\
Minturun) & & \\
\end{tabular} \\
\hline 2017 & Surat Kabar dan Brosur & \begin{tabular}{|llll} 
Villa Anggrek III & (Lubuk \\
Minturun) & & \\
\end{tabular} \\
\hline
\end{tabular}

Sumber: PT. Bangun Persada Sejahtera Berdasarkan informasi yang didapatkan pada PT. Bangun Persada Sejahtera untuk menarik perhatian konsumen, khalayak umum maka PT. Bangun Persada Sejahtera melakukan kegiatan promosi perumahan melalui Surat Kabar yang ada di kota Padang dan melalui brosur Pemilikan Rumah.

Tabel 2

Data Jumlah Komplain Konsumen Atas Perumahan yang Dikelola PT. Bangun Persada Sejahtera

\begin{tabular}{|c|c|c|c|c|}
\hline Tahun & $\begin{array}{c}\text { Spesifikasi } \\
\text { bangunan } \\
\text { tidak sesuai }\end{array}$ & $\begin{array}{c}\text { Terlambat } \\
\text { serah terima } \\
\text { unit }\end{array}$ & $\begin{array}{c}\text { Uang muka } \\
\text { dan } \\
\text { Kenaikan } \\
\text { Biaya }\end{array}$ & $\begin{array}{c}\text { Lepas } \\
\text { tanggung } \\
\text { jawab }\end{array}$ \\
\hline 2015 & 20 & 20 & 20 & 20 \\
\hline 2016 & 20 & 20 & 20 & 20 \\
\hline 2017 & 15 & 15 & 15 & 15 \\
\hline
\end{tabular}

Sumber: PT. Bangun Persada Sejahtera

Adapun jumlah data yang didapatkan tersebut adalah data konsumen yang telah mencakup semua jenis komplain yang dilakukan kepada PT. Bangun Persada Sejahtera, dalam kasus ini pengembang kerap

\footnotetext{
${ }^{9}$ Wawancara dengan Bapak Herbert Hutabarat, Direktur PT. Bangun Persada Sejahtera, pada tanggal 23 Maret 2017.
} 
kali lalai menepati janji yang sebelumnya disepakati atau tercantum di brosur promosi. Perbedaaan spesifikasi bangunan seperti luas ukuran tanah merupakan kelalaian yang bisa berakibat fatal semisal ukuran yang tertulis di surat dokumen berbeda dari kondisi aslinya.

PEMBAHASAN

Perlindungan Hukum Terhadap Konsumen Atas Informasi Iklan Perumahan Yang Menyesatkan Dalam Perjanjian Kepemilikan Rumah Oleh PT. Bangun Persada Sejahtera

Perlindungan hukum bagi konsumen dalam pengaturan hak dan kewajiban para pihak dapat dilihat di bawah ini. Bahwa dalam suatu hubungan hukum, muncul kewajiban dan hak masing-masing pihak. Kewajiban PT. Bangun Persada Sejahtera adalah sebagai berikut:

1. Menyiapkan syarat-syarat kelengkapan pendirian rumah atau bangunan rumah.

2. Melaksanakan pendirian bangunan sesuai waktu yang telah ditetapkan menurut gambar arsitektur.

3. Menyelesaikan pendirian bangunan dan menyerahkan tanah dan bangunan rumah tepat waktu seperti yang diperjanjikan kepada pembeli.
4. Mengurus pendaftaran perolehan hak atas tanah dan bangunan rumah.

5. Memberikan pelayanan atau perlakuan yang sama kepada calon konsumen.

6. Memberikan informasi yang jelas dan terbuka berkaitan dengan pengajuan pembelian rumah oleh calon konsumen.

7. Memberikan daftar yang berisikan syaratsyarat dalam pengajuan pembelian rumah secara kredit lengkap dengan tabel angsuran yang menyajikan persyaratan yang diperlukan dan tata caranya dalam pembelian rumah.

Di dalam Pasal 7 Undang-Undang Nomor 8 Tahun 1999 tentang Perlindungan Konsumen, kewajiban pelaku usaha adalah: 1 . beritikad baik dalam melakukan kegiatan usahanya; 2. memberikan informasi yang benar, jelas dan jujur mengenai kondisi dan jaminan barang dan/atau jasa serta memberi penjelasan penggunaan, perbaikan dan pemeliharaan; 3. memperlakukan atau melayani konsumen secara benar dan jujur serta tidak diskriminatif; 4. menjamin mutu barang dan/atau jasa yang diproduksi dan/atau diperdagangkan berdasarkan ketentuan standar mutu barang dan/atau jasa yang berlaku; 5. Memberi kesempatan kepada konsumen untuk menguji, dan/atau mencoba barang dan/atau jasa tertentu serta memberi jaminan dan/atau garansi atas barang yang dibuat dan/atau yang diperdagangkan; 6 . memberi kompensasi, ganti rugi dan/atau penggantian atas kerugian akibat penggunaan, 
pemakaian dan pemanfaatan barang dan/atau jasa yang diperdagangkan; 7. Memberi kompensasi, ganti rugi dan/atau penggantian apabila barang dan/atau jasa yang diterima atau dimanfaatkan tidak sesuai dengan perjanjian.

Menurut Penulis, kewajiban PT. Bangun Persada Sejahtera belum sesuai dengan ketentuan Pasal 7 huruf a, b, c, dan g Undang-Undang Nomor 8 Tahun 1999 tentang Perlindungan Konsumen. Kewajiban PT. Bangun Perdana Sejahtera tersebut diatas, dimana pelaku usaha belum beritikad baik dalam melaksanakan kegiatan usahanya, tidak memberikan informasi yang benar, jelas dan jujur mengenai kondisi dan jaminan barang, tidak memberi penjelasan penggunaan, perbaikan dan pemeliharaan, tidak memperlakukan atau melayani konsumen secara benar dan jujur serta tidak diskriminatif, serta memberi jaminan atau garansi atas barang yang diperdagangkan.

Dari beberapa aturan perundangundangan yang ada, baik KUHPerdata maupun Undang-Undang Nomor 8 Tahun 1999 tentang Perlindungan Konsumen, jelaslah bahwa penggunaan perjanjian baku tidaklah dilarang. Perjanjian baku tetap dianggap sah apabila sesuai dengan syaratsyarat sah perjanjian berdasarkan Pasal 1320 KUHPerdata, dan isinya tidak bertentangan dengan Pasal 18 Undang-Undang Nomor 8 Tahun 1999 tentang Perlindungan Konsumen.
Untuk Putusan Pengadilan Negeri tentang keberatan atas Putusan BPSK tersebut, apabila para pihak merasa dirugikan dapat melakukan upaya hukum lanjutan. Berdasarkan Pasal 72 Undang-Undang Arbitrase dan APS, dirumuskan bahwa terhadap putusan Pengadilan Negeri tersebut, para pihak yang merasa dirugikan dengan putusan tersebut mengajukan permohonan Banding langsung ke Mahkamah Agung, tidak ke Pengadilan Tinggi.

Untuk perkara banding, Mahkamah Agung bertugas dan berwenang memeriksa, mengadili, dan memutus perkara banding dalam tingkat pertama dan terakhir. Jadi banding adalah upaya hukum terakhir, tidak ada lagi upaya hukum lainnya yang dapat dilakukan oleh para pihak atas pembatalan putusan sengketa konsumen.

\section{Tanggung Jawab PT. Bangun Persada} Sejahtera Terhadap Informasi Iklan Perumahan yang Menyesatkan yang Menyebabkan Kerugian Kepada Konsumen

Berbagai penawaran yang dilakukan oleh pengembang untuk mempromosikan dan memasarkan perumahannya. Pada umumnya, pemasaran perumahan dilakukan dengan menggunakan sarana iklan atau brosur sebagai sarana mengkomunikasikan produkproduk yang dibuat dan/atau dipasarkan oleh pengembang kepada konsumennya. Kegiatan promosi dilakukan oleh pengembang untuk 
mengenalkan atau menyebarluaskan informasi dari produk yang telah dibuat pengembang. Iklan melalui brosur tersebut, juga untuk menarik minat beli konsumen perumahan terhadap produk perumahan yang dipasarkan.

Alasan masyarakat membeli perumahan dari pengembang adalah masyarakat dapat memperoleh perumahan secara lebih cepat, lebih terjangkau, dan tidak repot. Melalui pengembang, konsumen juga dapat memilih bangunan rumah yang sesuai dengan keinginan serta mendapatkan fasilitas umum maupun fasilitas social yang melengkapi perumahan nantinya akan menjadi tempat tinggal konsumen. Namun, kepercayaan masyarakat seringkali disalahgunakan oleh pengembang, dalam melakukan penawaran perumahan tidak jarang informasi yang diberikan oleh pengembang terlalu berlebihan sehingga membuat konsumen tertarik atau mungkin bahkan membingungkan bagi konsumen sendiri.

Perumahan Villa Anggrek Lubuk Minturun yang berupa perumahan biasa dan bersubsidi gdari pemerintah, sistem penawaran perumahan Villa Anggrek juga dilakukan dengan mempergunakan brosur. Dalam Brosur penawaran perumahan tersebut hanya mencantumkan mengenai perspektif bangunan, denah rumah, dan spesifikasi bangunan rumah.
Informasi dalam brosur tersebut jika tidak dicermati secara mendalam memang terkesan tidak ada masalah bagi konsumen perumahan Villa Anggrek, karena informasi tersebut bersifat umum. Namun, dalam realitasnya informasi tersebut mengandung makna ambigu (ganda). Hal ini berkaitan dengan kualitas bahan bangunan perumahan Villa Anggrek yang direalisasikan oleh pengembang PT. Bangun Persada Sejahtera, dimana kualitas bangunannya beradadi bawah standar kualitas bangunan layak huni. Setelah dimintakan klarifikasi dengan Tuan SR salah satu penghuni perumahan Villa Anggrek, dapat diketahui kualitas bangunan perumahan Villa Anggrek berada dibawah standar konstruksi bangunan layak huni.

Adanya permasalahan dalam kualitas bangunan tersebut, mengakibatkan konsumen Villa Anggrek perlu memperbaiki bangunan rumahnya bahkan mengganti dengan yang baru demi kenyamanan dan keamanan penghuni. Dari pihak pengembang PT. Bangun Persada Sejahtera hanya mengecek keluhan konsumen perumahan Villa Angrek sebelum penyerahan rumah, kemudian pihak pengembang memperbaikinya. Namun, mayoritas permasalahan bangunan yang dirasakan konsumen perumahan Villa Anggrek dirasakan setelah penyerahan kunci, sehingga tidak ada tindak lanjut dari pihak pengembang. Padahal setelah penyerahan kunci kepada penghuni pihak pengembang masih mempunyai kewajiban untuk melayani 
keluhan konsumennya dalam waktu 100 (seratus) hari.

Dengan memberikan informasi yang tidak benardan tidak jujur kepada konsumen perumahan Villa Anggrek, maka pengembang PT.Bangun Persada Sejahtera dalm menawarkan, mempromosikan, atau mengiklankan perumahan Villa Anggrek telah melanggar Undang-Undang Nomor 8 Tahun1999 tentang Perlindungan Konsumen yaitu Pasal 7 huruf $b$ dan d juncto Pasal 9 Juncto Pasal 10 huruf c juncto Pasal 17 ayat (1) huruf a dan c UUPK.

Pasal 7 huruf $b$ dan $d$ UUPK memberikan kewajiban-kewajiban kepada pelaku usaha, yang dalam hal ini adalah pengembang PT. Bangun Persada Sejahtera, dalam melakukan kegiatan usaha perumahannya. Dengan adanya kewajibankewajiban tersebut diatas, maka pengembang sebagai pelaku usaha tidak diperkenankan memberikan informasi dalam brosur pemasaran yang tidak sesuai dengan kenyataannya. Penawaran produk melalui brosur yang tidak sesuai dengan kenyataannya jelas akan menimbulkan kerugian bagi pihak masyarakat selaku konsumen perumahan.

$$
\text { Pasal } 9 \text { ayat (1) huruf a UUPK }
$$
mengatur mengenai larangan pelaku usaha dalam menawarkan, mempromosikan, mengiklankan suatu barang dan/atau jasa secara tidak benar dan/atau seolah-olah barang tersebut telah memenuhi dan/atau memiliki potongan harga, harga khusus,

standar mutu tertentu, gaya atau mode tertentu, karakteristik tertentu, sejarah atau guna tertentu. Adanya penggunaan standar mutu bangunan di bawah standar, maka pengembang PT.Bangun Persada Sejahtera telah menawarkan, mempromosikan, mengiklankan perumahan Villa Anggrek secara tidak benar. Bahkan dalam brosur penawaran dari pengembang PT. Bangun Persada Sejahtera tidak mencantumkan secara terperinci kualitas bahan bangunannya dalam spesifikasi bangunan. Adanya informasi bahan bangunan yang tidak rinci dalam brosur penawaran perumahan mengakibatkan konsumen tidak dapat mengetahui bahan bangunan rumah yang akan ditinggalinya.

Pasal 10 huruf c UUPK mengatur mengenai pelaku usaha dalam menawarkan barang dan/atau jasa yang ditujukan untuk diperdagangkan dilarang menawarkan, mengiklankan, atau membuat pernyataan yang tidak benar atau menyesatkan mengenai kondisi, tanggungan, jaminan, hak atau ganti rugi atas suatu barang dan/atau jasa. Informasi kondisi bahan bangunan perumahan Villa Anggrek dalam brosur penawaran tidak dicantumkan secara transparan sehingga konsumen dapat disesatkan dengan informasi tersebut karena ternyata dalam prakteknya kondisi bangunan perumahan Villa Anggrek adalah tidak memenuhi Standan Nasional Indonesia untuk bahan bangunan perumahan yang layak huni. 
Ada kalanya kerusakan konstruksi rumah tidak bisa langsung ditemukan pada saat pemeriksaan awal. Kerusakan dapat saja terjadi beberapa waktu setelah rumah diserahterimakan kepada konsumen. Untuk memberikan perlindungan terhadap konsumen atas masalah seperti itu, maka masa garansi pemeliharaan ditetapkan selama 100 hari (seratus) hari kalender terhitung sejak penyerahan rumah dari PT. Bangun Persada Sejahtera kepada konsumen. Apabila keluhan mengenai keruskan konstruksi rumah melebihi atau diluar jangka waktu tersebut, maka sudah tidak lagi menjadi tanggung jawab PT. Bangun Persada Sejahtera.

\section{PENUTUP}

Bentuk perlindungan hukum atas informasi iklan perumahan yang menyesatkan, yang dilakukan oleh pengembang PT. Bangun Persada Sejatera terhadap konsumen perumahan Villa Anggrek, sebagai pihak yang dirugikan dapat melakukan berbagai upaya hukum untuk memperjuangkan haknya adalah dalam bentuk ganti rugi yang diperoleh melalui gugatan yang diselesaikan baik secara litigasi maupun non litigasi.

Tanggung jawab PT. Bangun Persada Sejahtera terhadap informasi iklan perumahan yang menyesatkan kepada konsumen adalah mengupayakan setiap perbaikan yang dikeluhkan oleh konsumen. Apabila konsumen merasa dirugikan oleh pihak pelaku usaha maka pihak pelaku usaha wajib memberikan kompensasi, ganti rugi dan/atau penggantian atas kerugian yang diakibatkan oleh pengguna, pemakai dan pemanfaatan barang dan/atau jasa yang telah diperdagangkan.

\section{DAFTAR PUSTAKA}

\section{Buku}

Amirudin dan Zaenal Asikin, 2006. Pengantar Metode Penelitian Hukum, Raja Grafindo Persada, Jakarta.

Dedi Harianto. 2010. Perlindungan Hukum Bagi Konsumen Terhadap Iklan Yang Mnyesatkan, Ghalia Indonesia. Bogor.

Janus Sidabalok, 2006. Hukum Perlindungan Konsumen di Indonesia,Bandung.PT Citra AdityaBakti.

Ronny Hanitijo Soemitro, 2002. Metodologi Penelitian Hukum dan Jurimetri, Sinar Grafika, Jakarta.

Yusuf Shofie, 2009. Perlindungan Konsumen dan Instrumen - instrumen Hukumnya, PT. Citra Aditya Bakti, Bandung.

Zulkarnaen , 2008. Perlindungan Hukum Terhadap Konsumen Barang Barang Elektronik.PT. Gramedia, Semarang.

\section{Undang - Undang}

Undang-Undang Dasar Negara Republik Indonesia Tahun 1945

Undang-Undang Nomor 8 Tahun 1999 tentang Perlindungan Konsumen

Undang-Undang Nomor 18 Tahun 1999 tentang Jasa Konstruksi

Undang-Undang Nomor 32 Tahun 2002 tentang Penyiaran Ikla 
Undang-Undang Nomor 1 Tahun 2011 tentang Perumahan dan Kawasan Permukiman

Peraturan Pemerintah Nomor 58 Tahun 2001 tentang Pembinaan Pengawasan dan Penyelenggaraan Perlindungan Konsumen

Peraturan Pemerintah Republik Indonesia Nomor 64 Tahun 2016 tentang Pembangunan Perumahan Masyarakat Berpenghasilan Rendah

Peraturan Menteri Pekerjaan Umum Dan Perumahan Rakyat Republik Indonesia Nomor 26/PRT/M/2016 tentang Perubahan Atas Peraturan Menteri Pekerjaan Umum Dan Perumahan Rakyat Nomor 21/PRT/M/2016 tentang Kemudahan dan/atau Bantuan Perolehan Rumah Bagi Masyarakat Berpenghasilan Rendah

Surat Edaran Dirjen Perdagangan Dalam Negeri Nomor 235/DJPDN/VII/2001 tentang PenangananPengaduan Konsumen yang ditujukan kepada seluruh dinas Indag Prop/Kab/Kota

Surat Edaran Direktur Jenderal Perdagangan Dalam Negeri Nomor 795 /DJPDN/SE/12/2005 tentang Pedoman Pelayanan Pengaduan Konsumen 